\title{
Immunohistochemical and histochemical identification of proteins and carbohydrates in the equine endometrium: Reaction patterns in the cycling mare
}

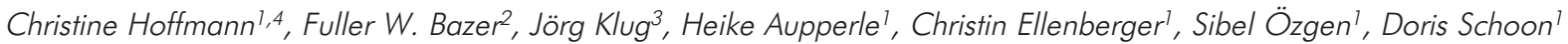 \\ und Heinz-Adolf Schoon?
}

Institute of Veterinary Pathology of the Faculty of Veterinary Medicine, University of Leipzig ', Dept. of Animal Science, Texas A\&M University, College Station², Institute of Anatomy and Cell Biology of the Faculty of Medicine, Justus-Liebig University Gießen ${ }^{3}$ and Friedrich-Loeffler-Institut, Institute of Novel and Emerging Infectious Diseases, Greifswald-Insel Riems ${ }^{4}$

\begin{abstract}
Summary
Little is known about the stage of estrus cycle-dependent variations of uterine secretions of the mare and most published results were based on evaluation of uterine flushings. Hence, the aim of this study was to define patterns of expression of different endometrial proteins throughout the estrus cycle using newly established immunohistochemical methods and endometrial biopsies. Therefore, endometrial biopsies were collected from three mares on defined days of the estrus cycle with known concentrations of estradiol and progesterone in serum. The proteins uteroglobin, uteroferrin, calbindin ${ }_{D 9 k}$ and uterocalin were examined using polyclonal antibodies. Furthermore glycogen was identified using the PAS-reaction prior to and after $\alpha$-amylase digestion. During the estrus cycle expression of the examined proteins, as well as glycogen, revealed a typical, progesterone-dependent pattern. In the early- and mid-interestrus there is a simultaneous increase in expression of uterocalin and glycogen staining intensity associated with increasing concentrations of progesterone in peripheral blood. The maximal expression of calbindin ${ }_{D 9 k}$ was also in association with high levels of circulating progesterone in mid-interestrus. In contrast, secretion of both uteroglobin and uteroferrin was simultaneously associated with the decrease in circulating concentrations of progesterone in midto late-interestrus. However, it has to be emphasized that distinct among mare differences were obvious. This new method enables pathologists to interpret changes in the uterine secretion pattern associated with fertility reducing diseases by using a single endometrial biopsy.
\end{abstract}

Keywords: mare, cycle, biopsy, uterine secretions, immunohistochemistry

Immunhistologischer und histochemischer Nachweis endometrialer Proteine und Kohlenhydrate im equinen Endometrium im Verlauf des Zyklus

Zu den zyklusabhängigen Variationen des uterinen Sekretionsmuster der Stute ist wenig bekannt, die meisten Publikationen basieren zudem auf Untersuchungen uteriner Spülproben. Ziel dieser Studie ist daher, das Expressionsmuster verschiedener endometrialer Proteine im Verlauf des Zyklus an Endometriumbiopsien mittels neu etablierter immunhistologischer Methoden darzustellen. Es standen, an definerten Zyklustagen entnommene Endometriumbiopsien dreier Stuten mit bekannten Östrogen- und Progesteronkonzentrationen im Serum zur Verfügung. Die Proteine Uteroglobin, Uteroferrin, calbindin ${ }_{\mathrm{D} 9 \mathrm{~K}}$ und Uterocalin konnten mittels polyklonaler Antikörper dargestellt werden, zum Nachweis von Glykogen wurde eine PAS-Reaktion vor und nach Verdauung mit $\alpha$-Amylase durchgeführt. Alle untersuchten Proteine wie auch das Glykogen zeigten während des Zyklusverlaufs ein typisches progesteronabhängiges Reaktionsmuster. So erfolgte der Anstieg des Uterocalin- und Glykogennachweises gleichzeitig mit dem des Progesterons im frühen und mittleren Interöstrus. Das Calbindin ${ }_{D 9 K} z$ zeigt eine enge Assoziation mit dem im mittleren Interöstrus auftretenden Progesteronpeak. Im Gegensatz dazu konnte eine zeitverzögerte, mit dem im mittleren bis späten Interöstrus auftretenden Abfall der Progesteronwerte assoziierte Expression von Uteroglobin und Uteroferrin beobachtet werden. Es muss jedoch betont werden, dass zwischen den einzelnen Stuten teils deutliche Unterschiede in der Expression der untersuchten Proteine und des Glykogens auftraten. Mit den hier vorgestellten neven Methoden besteht nun die Möglichkeit, anhand einer Endometriumbiopsie eine morphologisch-funktionelle Beurteilung der uterinen Sekretion insbesondere im Rahmen fertilitätsrelevanter Erkrankungen durchzuführen.

Schlüsselwörter: Stute, Zyklus, Biopsie, uterines Sekretionsmuster, Immunohistochemie

\section{Introduction}

It is well known that in all mammalian species the early conceptus is bathed in uterine secretions, histotroph, prior to implantation and development of the placenta. A significant increase in macromolecules, predominantly proteins, characterize histotroph milieu during the preimplantation stage of uterine "receptivity", that facilitates implantation (Beier-Hellwig et al. 1995). However, in species like the horse, in which the trophoblast is non-invasive, uterine secretions are more likely to play an important role in development and survival of the conceptus (Amoroso 1959) and are more abundant due to accumulation of endometrial secretory proteins during the luteal phase as compared to other mammalian species (Beier-Hellwig et al. 1995).

Progesterone-dependent synthesis and secretion is associated with a time-lag of several days and has been described for 
Uteroglobin (UGL) and Uteroferrin (UF) in different species including the mare. One of the major proteins, secreted only by the endometrium of the mare is Uterocalin (UCA) (BeierHellwig et al. 1995). The expression of this protein correlates well with serum progesterone concentrations and can be stimulated by administering exogenous progesterone to the anestrous mares (Stewart et al. 1995, Crosset et al. 1998). Distinct species differences have been reported regarding the regulation of calbindin ${ }_{\mathrm{D} 9 \mathrm{k}}(\mathrm{CAL})$ during the estrus cycle. While in bovine (Inpanbutr et al. 1994) and murine (Tatsumi et al. 1999) endometrium its expression seems to depend on progesterone, a positive influence of estrogen has been shown in the rat endometrium (L'Horset et al. 1993). However, there are no reports on its expression in the equine endometrium. The endometrial glycogen (GLY) has only been rarely investigated in the mare (Freeman et al. 1990, Gilbert 1992) but a progesterone dependency was demonstrated for other species (Jaffe et al. 1985). The function of the histotroph is different, but a nutritional purpose is assumed for GLY (Freeman et al. 1990), CAL (Nikitenko et al. 1998), UF (Roberts et al. 1986) and UCA (Crosset et al. 1998). However, the role of UGL is unknown, antiinflammatory and antichemotactic properties have been proposed for other tissues (Mukheriee et al. 1999).

Except for UCA, detailed studies of stage of estrus cycledependent variations in expression and secretion of equine endometrial proteins and GLY have not been reported. The present study used endometrial biopsies to examine the reaction pattern of GLY and selected endometrial proteins by using histochemical and newly established immunohistochemical methods. As a result there is now the possibility to interpret and correlate changes in patterns of uterine secretions with diseases that reduce fertility by using a single endometrial biopsy.

\section{Material and Methods}

Animals

In total 21 endometrial biopsies obtained from three gynecologically healthy Warmblood mares, aged $7(n=2)$ to 11 $(n=1)$ years, were studied. The biopsies were taken at day 0 (ovulation), 5, 10, 13, 16 and 19 of the estrus cycle and the concentrations of estradiol and progesterone in serum were determined (Table 1) by radioimmunoassay simultaneously.

\section{Histology}

The samples were fixed in $4 \%$ buffered formalin, embedded in paraplast, sectioned at 3-4 $\mu \mathrm{m}$ and stained with haematoxylin and eosin. The histopathological examination of the biopsies as well as the classification of the morphological criteria of endometrial differentiation were performed as described previously (Schoon et al. 1997).

\section{Histochemistry}

The PAS-reaction prior to and after $\alpha$-amylase digestion of the sections was used to identify glycogen within the uterine glandular epithelia.

\section{Immunohistochemistry}

Immunohistochemistry was performed using the Peroxidase-antiperoxidase technique as described elsewhere (Hoffmann et al. 2009). Mouse-anti human estrogen receptor ${ }^{1}$, mouse anti-human progesterone receptor ${ }^{2}$, mouse anti-human Ki-67-antigen', as well as the rabbit polyclonal antibodies to uteroglobin ${ }^{3}$, uterofer$\mathrm{rin}^{4}$, uterocalin ${ }^{5}$ and calbindin ${ }_{\mathrm{D} 9 \mathrm{k}}{ }^{6}$ served as primary antibodies.

\section{Immunohistochemical analysis}

For precise assessment of the endometrial protein and glycogen reaction intensities, the method used to evaluate steroid hormone receptor expression in carcinoma of the human breast was modified and adjusted to special requirements of the equine endometrium in order to carry out an objective assessment of the staining reaction. Therefore the proportion of immunolabelled cells was defined as the ratio of labeled cells to the total number of cells in ten HBFs and the values were expressed as a "percentage of positive cells" (PP). In the process, the staining intensity (SI) of immunolabelled cells was assessed and assigned to numerical values (Index n). The so called Secretion Score (SSc) was calculated using the formula described below:

$$
\begin{gathered}
\mathrm{SSC}=1 / 100 \sum_{\mathrm{n}=2}^{4}\{\mathrm{PPn} \times \max [\varphi \times(\operatorname{SIn}-1), 1]\} \\
\mathrm{n}=\text { Index, PP=Percentage of positive cells PP } \\
\text { Weight }=5, \mathrm{SI}=\text { Staining Intensity }
\end{gathered}
$$

\begin{tabular}{|c|c|c|c|c|c|c|c|}
\hline & \multirow[b]{2}{*}{ day of cycle } & \multicolumn{2}{|c|}{ Mare A } & \multicolumn{2}{|c|}{ Mare B } & \multicolumn{2}{|c|}{ Mare C } \\
\hline & & $\mathrm{E}(\mathrm{pg} / \mathrm{ml})$ & $P(\mathrm{ng} / \mathrm{ml})$ & $E(p g / m l)$ & $\mathrm{P}(\mathrm{ng} / \mathrm{ml})$ & $E(p g / m l)$ & $\mathrm{P}(\mathrm{ng} / \mathrm{ml})$ \\
\hline Estrus & Ovulation & 23,3 & 0,52 & 3,1 & 0,02 & 0,9 & 0,11 \\
\hline Early interestrus & 5 & 17,3 & 7,5 & 4,0 & 1,6 & 2,5 & 3,6 \\
\hline \multirow[t]{2}{*}{ Mid interestrus } & 10 & 16,8 & 0,67 & 3,0 & 2,6 & 4,6 & 3,5 \\
\hline & 13 & 14,1 & 0,52 & 3,6 & 0,58 & 10,4 & 0,24 \\
\hline \multirow[t]{2}{*}{ Late interestrus } & 16 & 18,1 & 0,47 & 7,0 & 0,05 & 9,5 & 0,18 \\
\hline & 19 & 29,3 & 0,26 & 2,4 & 0,06 & 0,9 & 0,33 \\
\hline Proestrus & 21 & 19,5 & 0,27 & 1,2 & 1,5 & -- & -- \\
\hline
\end{tabular}

Table 1 Serum concentrations of sex steroids throughout the estrous cycle. Serumkonzentration der Sexualhormone während des Zyklusverlauf 
Assignment of staining intensity and SI value

\begin{tabular}{cccc}
\hline Index $\mathbf{n}$ & SI & Reaction pattern & value \\
\hline 1 & none & none & 0 \\
2 & slight & very weak, fine granular & 1 \\
3 & weak & clear, fine granular & 2 \\
4 & moderate & globular to confluent & 3 \\
5 & strong & very strong, confluent & 4 \\
\hline
\end{tabular}

The SSc can reach a numerical value between 0 (none immunhistochemical reaction) and 10 (strongest immunohistochemical reaction).

\section{Results}

Although there were among mare differences concerning day of cycle-dependent changes in steroid hormone concentrations, the collected data are presented to correspond with the defined values for each mare (Table 1). Moreover, the histomorphological and immunohistochemical characteristics of the endometria analyzed during the estrus cycle for each of the three mares were in accordance with expectations from previous reports (Aupperle et al. 2000).

The staining intensity for the selected proteins and GLY determined with respect to stage of cycle and cell-specificity were found to display typical reaction patterns throughout the estrus cycle.

\section{Uteroglobin (Table 2, Fig. 1 and 2)}

The maximal reaction pattern for UGL in uterine glands was in mid- to late-interestrus associated with decreasing concentra- tions of peripheral progesterone in all three mares. A second peak of UGL expression was detected during proestrus/estrus of mare $B$ and at estrus of mare $C$. Besides these periods of peak expression a mild to moderate staining intensity was observed in all mares throughout the estrus cycle.

\section{Uteroferrin (Table 2, Fig. 3)}

The maximal glandular staining intensity of UF was in midinterestrus (mares A and C) and mid- to late interestrus (mare B). As for UGL, expression of UF was coupled to cycle dependent decreases in concentrations of serum progesterone. At other time points of the estrus cycle UF was not or only weakly detectable.

\section{Calbindin $_{D 9 k}($ Table 3, Fig. 4)}

There were clear differences in the expression patterns of CAL among the mares. While less than $20 \%$ of the endometrial glandular epithelial cells expressed CAL in mare A, a distinct increase in positively stained cells was detected in early- to mid-interestrus of mares B $(70 \%$ of the cells) and C $(80 \%$ of the cells). However, the staining intensity was slight (mare C) to weak (mare B). Associated with increasing serum progesterone concentration, an additional increase in CAL expressing cells $(90 \%$ of cells) was observed in the proestrus of mare B. Only single cells expressed calbindin ${ }_{D 9 k}$ at all other time points investigated.

\section{Uterocalin (Table 3, Fig.4)}

Between estrus and early- to mid-interestrus, there was a continuous increase in UCA expression in uterine gland epithe-

Table 2 Cycle dependent variations of the uteroglobin and uteroferrin secretion-score with respect to concentrations of progesterone in serum Zyklusabhängige Veränderung des Uteroglobins und Uteroferrins (Sekretions-Score) mit Bezug zu den Serumprogesteronwerten

\begin{tabular}{|c|c|c|c|c|c|c|c|}
\hline \multirow[t]{2}{*}{ Day of cycle } & \multirow[t]{2}{*}{ Phase of cycle } & \multicolumn{2}{|c|}{ Mare A } & \multicolumn{2}{|c|}{ Mare B } & \multicolumn{2}{|c|}{ Mare C } \\
\hline & & SSc & $P(n g / m l)$ & SSc & $P(\mathrm{ng} / \mathrm{ml})$ & $\mathrm{SSc}$ & $P(\mathrm{ng} / \mathrm{ml})$ \\
\hline \multicolumn{8}{|l|}{ Uteroglobin } \\
\hline Ov. & estrus & 1,9 & 0,52 & 4,3 & 0,02 & 2,9 & 0,11 \\
\hline 5 & early interestrus & 2 & 7,5 & 2,5 & 1,6 & 1,6 & 3,6 \\
\hline 10 & mid interestrus & 2,5 & 0,67 & 1,3 & 2,6 & 1 & 3,5 \\
\hline 13 & & 2 & 0,52 & 2,7 & 0,58 & 1,4 & 0,24 \\
\hline 16 & late interestrus & 0,5 & 0,47 & 2,7 & 0,05 & 1,5 & 0,18 \\
\hline 19 & & 0,9 & 0,26 & 1,3 & 0,06 & 1 & 0,33 \\
\hline 21 & Proestrus & 0,9 & 0,27 & 3,1 & 1,5 & -- & -- \\
\hline \multicolumn{8}{|l|}{ Uteroferrin } \\
\hline Ov. & estrus & 0,4 & 0,52 & 0,8 & 0,02 & 0,2 & 0,11 \\
\hline 5 & early interiestrus & 0,2 & 7,5 & 0 & 1,6 & 0,3 & 3,6 \\
\hline 10 & mid interestrus & 2,2 & 0,67 & 0 & 2,6 & 0 & 3,5 \\
\hline 13 & & 0,2 & 0,52 & 1,5 & 0,58 & 1,7 & 0,24 \\
\hline 16 & late interestrus & 0,7 & 0,47 & 1 & 0,05 & 0 & 0,18 \\
\hline 19 & & 0 & 0,26 & 0,3 & 0,06 & 0,2 & 0,33 \\
\hline 21 & proestrus & 0 & 0,27 & 0,4 & 1,5 & -- & -- \\
\hline
\end{tabular}


lium which was associated with increasing concentrations of progesterone in serum. A second peak of staining intensity in uterine glands was detected in late interestrus for mare $A$ with no correlation to serum hormone levels or steroid hormone receptor expression. Only weak staining intensities were seen at all other time points of the cycle.

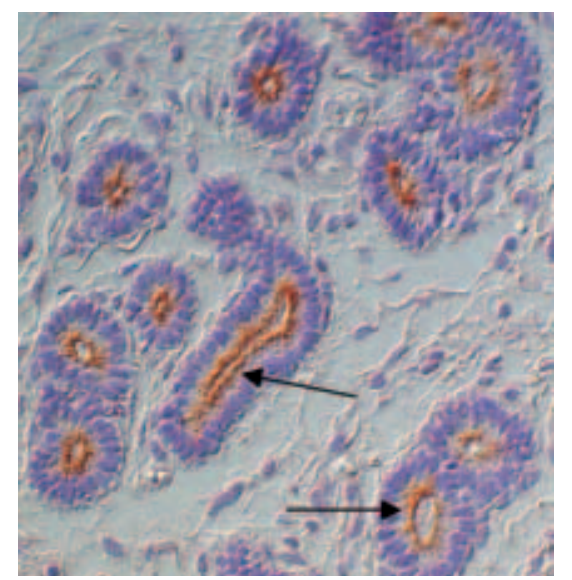

Fig 1 Cycle dependent glandular expression of the different proteins examined. Uteroglobin: Mare A, 10th day post-ovulation: epithelium of the middle uterine glands showed a uniform and predominantly apical intracytoplasmatic reaction pattern for uteroglobin (arrows). Immunohistochemistry, anti-uteroglobin, magnification 62,5x

Zyklusabhängige Expression der untersuchten Proteine in den Uterindrüsen. Uteroglobin, Stute A, 10. Tag post-ovulationem, mittlerer Bereich des Stratum spongiosum, gleichmäßiges, vorwiegend apikales intrazytoplasmatisches Expressionsmuster (Pfeile) des Uteroglobins im glandulären Epithel. Immunhistochemie, Anti-Uteroglobin, Vergrößerung 62,5x

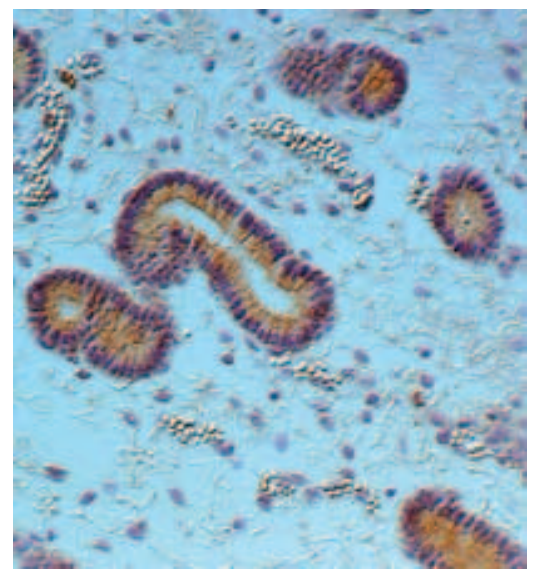

Fig. 3 Cycle dependent glandular expression of the different proteins examined. Uteroferrin: Mare B, 13th day post-ovulation, middle uterine glands, all glandular epithelial cells within one gland showed a uniform diffuse intracytoplasmatic expression pattern for uteroferrin. Immunohistochemistry, anti-uteriferrin, magnification 62,5x

Zyklusabhängige Expression der untersuchten Proteine in den Uterindrüsen. Uteroferrin, Stute B, 13. Tag post-ovulationem, mittlerer Bereich des Stratum spongiosum, diffuses intrazytoplasmatisches innerhalb des Drüsenquerschnittes gleichmäßig exprimientes Uteroferrin. Immunohistochemie, Anti-Uteroferrin, Vergrößerung 62,5x

\section{Glycogen (Table 4)}

Corresponding to increasing serum progesterone concentrations, an increased accumulation of GLY in the uterine glands was observed between estrus and mid-interestrus in mares B and $C$. However, the maximal reaction pattern for GLY in mare A was at mid-interestrus without any association to changing concentrations of hormones in the blood or steroid hormone receptors. Apart from this reaction, moderate concentrations of GLY were detected in the uterine glands throughout the estrus cycle.

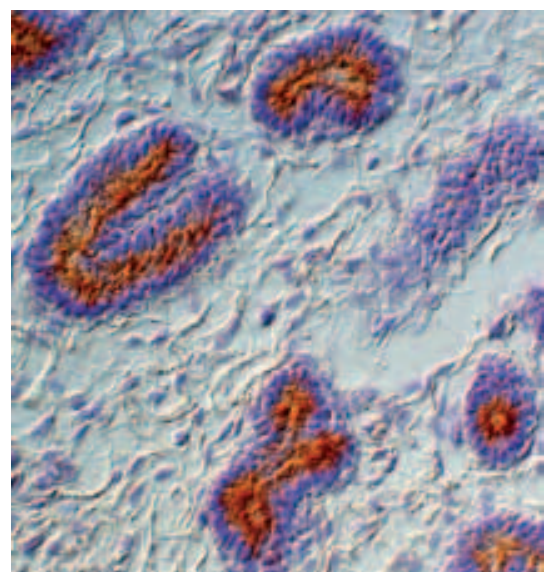

Fig. 2 Cycle dependent glandular expression of the different proteins examined. Uteroglobin: Mare B, ovulation (day 0): middle uterine gland, all glandular epithelia showed a uniform diffuse intracytoplasmatic reaction pattern of uteroglobin expression. Immunohistochemistry, anti-uteroglobin, magnification 62,5x

Zyklusabhängige Expression der untersuchten Proteine in den Uterindrüsen. B: Uteroglobin, Stute B, Ovulation (Tag 0), mittlerer Bereich des Stratum spongiosum, diffuses intrazytoplasmatisches gleichmäßiges Expressionsmuster des Uteroglobins in den glandulären Epithelien. Immunhistochemie, Anti-Ueroglobin, Vergrößerung $62,5 x$

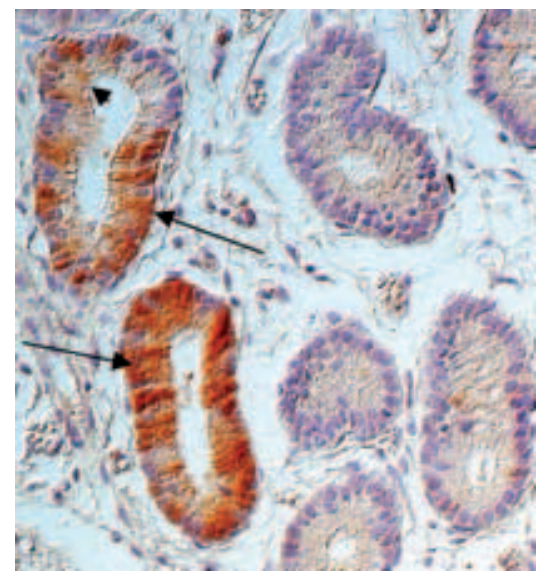

Fig. 4 Cycle dependent glandular expression of the different proteins examined. calbindin ${ }_{\mathrm{D} 9 \mathrm{~K}}$ : Mare B, 5th day post-ovulation, mosaic reaction pattern for calbindin ${ }_{D 9 k}$ expression. In single cells (arrows) within one gland, strong staining intensity can be observed while other cells show relatively weak or no staining (arrowheads), adjacent glands with no staining reaction. Immunohistochemistry,

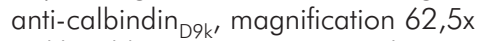

Zyklusabhängige Expression der untersuchten Proteine in den Uterindrüsen. Calbindin ${ }_{D 9 k^{\prime}}$ Stute B, 5. Tag post-ovulationem, mittlerer Bereich des Stratum spongiosum, deutlich erkennbares "mosaikartiges" Reaktionsmuster des Calbindins ${ }_{D K^{\prime}}$ Einzelne Zellen innerhalb eines Drüsenquerschnittes mit hochgradiger Expression des Proteins (Pfeile), daneben Epithelien mit schwacher Anfärbung (Pfeilspitze), benachbarte Epithelien ohne erkennbare Akkumulation des Proteins. Immunohistochemie, Anti-Calbindin ${ }_{D 9 k^{\prime}}$ VergröBerung 62,5x 
Table 3 Cycle dependent variations in calbindin ${ }_{D 9 k}$ and Uterocalin secretion-scores with respect to concentrations of progesterone in serum Zyklusabhängige Veränderung des Calbindin $_{\mathrm{D} 9 \mathrm{k}}$ und Uterocalins (Sekretions-Score) mit Bezug zu den Serumprogesteronwerten

\begin{tabular}{|c|c|c|c|c|c|c|c|}
\hline \multirow[t]{2}{*}{ Day of cycle } & \multirow[t]{2}{*}{ Phase of cycle } & \multicolumn{2}{|c|}{ Mare A } & \multicolumn{2}{|c|}{ Mare B } & \multicolumn{2}{|c|}{ Mare C } \\
\hline & & SSc & $P(\mathrm{ng} / \mathrm{ml})$ & SSc & $\mathrm{P}(\mathrm{ng} / \mathrm{ml})$ & SSc & $P(\mathrm{ng} / \mathrm{ml})$ \\
\hline \multicolumn{8}{|l|}{ Calbindin $_{\mathrm{D} 9 \mathrm{k}}$} \\
\hline Ov. & estrus & 0,01 & 0,52 & 0,3 & 0,02 & 0,06 & 0,11 \\
\hline 5 & early interestrus & 0,01 & 7,5 & 1,2 & 1,6 & 0,5 & 3,6 \\
\hline 10 & mid interestrus & 0,03 & 0,67 & 0,5 & 2,6 & 0,5 & 3,5 \\
\hline 13 & & 0,05 & 0,52 & 0 & 0,58 & 0,4 & 0,24 \\
\hline 16 & late interestrus & 0,02 & 0,47 & 0 & 0,05 & 0,02 & 0,18 \\
\hline 19 & & 0 & 0,26 & 0,5 & 0,06 & 0 & 0,33 \\
\hline 21 & proestrus & 0,1 & 0,27 & 1,4 & 1,5 & -- & -- \\
\hline \multicolumn{8}{|l|}{ Uterocalin } \\
\hline Ov. & estrus & 0,9 & 0,52 & 1,0 & 0,02 & 0,9 & 0,11 \\
\hline 5 & early interestrus & 2,0 & 7,5 & 2,3 & 1,6 & 1,9 & 3,6 \\
\hline 10 & mid interestrus & 1,0 & 0,67 & 3,0 & 2,6 & 2,6 & 3,5 \\
\hline 13 & & 0,0 & 0,52 & 3,3 & 0,58 & 1,3 & 0,24 \\
\hline 16 & late interestrus & 1,3 & 0,47 & 0,9 & 0,05 & 0,0 & 0,18 \\
\hline 19 & & 2,4 & 0,26 & 0,9 & 0,06 & 1,0 & 0,33 \\
\hline 21 & prostrus & 0,9 & 0,27 & 0,9 & 1,5 & -- & -- \\
\hline
\end{tabular}

Localisation of positively stained cells and intracellular reaction pattern

All endometrial proteins were occasionally detected in the uterine luminal epithelium but not GLY. While UGL, UF and GLY were predominantly detected in middle to deep uterine glands, UCA was typically detected in the superficial glandular epithelium. CAL expression was, on the one hand multifocal in that it was detected at all levels in the uterine glands, but on the other hand, there was a characteristic mosaic-like staining reaction (Fig. 4) among cells within one uterine gland. This pattern of expression was also occasionally seen with GLY. In contrast, uniform glandular staining reaction was seen with the other proteins examined (Fig. 1-3). Thereby an apical intracytoplasmatic staining pattern was obvious at the peak of UGL expression respectively with the decrease in intracellular concentrations of GLY.

\section{Discussion}

To the best of our knowledge these is the first immunohistochemical study describing the expression of UF and CAL in cycling mares. Thereby, results from healthy mares indicate among mare variations in stage of cycle-dependent patterns of expression of different equine endometrial proteins and GLY.

\section{Uteroglobin}

While a previous report described a continuous increase of the UGL expression from the first to the 10th day of the estrus cycle (Müller-Schöttle et al. 2003), this was only observed in mare $A$ in the present study. In contrast, both mares B and $C$ showed a peak of the immunostaining for UGL during estrus and interestrus. These differences may reflect individual differences in serum hormone profiles, as described for the

Table 4 Cycle dependent variations in glycogen secretion-scores with respect to concentrations of progesterone in serum.

Zyklusabhängige Veränderung des Glykogens (Sekretions-Score) mit Bezug zu den Serumprogesteronwerten.

\begin{tabular}{|c|c|c|c|c|c|c|c|}
\hline \multirow[t]{2}{*}{ Day of cycle } & \multirow[t]{2}{*}{ Phase of cycle } & \multicolumn{2}{|c|}{ Mare A } & \multicolumn{2}{|c|}{ Mare B } & \multicolumn{2}{|c|}{ Mare C } \\
\hline & & SSc & $P(\mathrm{ng} / \mathrm{ml})$ & SSc & $\mathrm{P}(\mathrm{ng} / \mathrm{ml})$ & SSc & $P(\mathrm{ng} / \mathrm{ml})$ \\
\hline Ov. & estrus & 2,6 & 0,52 & 3,7 & 0,02 & 2,4 & 0,11 \\
\hline 5 & early interestrus & 2,5 & 7,5 & 5,7 & 1,6 & 3,3 & 3,6 \\
\hline 10 & mid interestrus & 2,0 & 0,67 & 5,2 & 2,6 & 2,4 & 3,5 \\
\hline 13 & & 4,9 & 0,52 & 1,8 & 0,58 & 0,9 & 0,24 \\
\hline 16 & late interestrus & 2,0 & 0,47 & 2,1 & 0,05 & 0,7 & 0,18 \\
\hline 19 & & 1,5 & 0,26 & 2,6 & 0,06 & 1,1 & 0,33 \\
\hline 21 & proestrus & 1,2 & 0,27 & 1,2 & 1,5 & -- & -- \\
\hline
\end{tabular}


human endometrium (Kikukawa et al. 1988). In contrast to uterine secretions which showed highest levels of UGL during interestrus (Beier-Hellwig et al. 1995), a maximal peak of intracellular UGL were detectable at estrus by immunohistochemistry. However it remains unclear if this accumulated $U G L$ is being released into the uterine lumen or if it reflects an estrogen induced intraepithelial accumulation (Beier 2000). Nevertheless, the apical intracellular distribution and the positively stained material in the lumina of the glands, both detectable during interestrus, possibly correspond to a

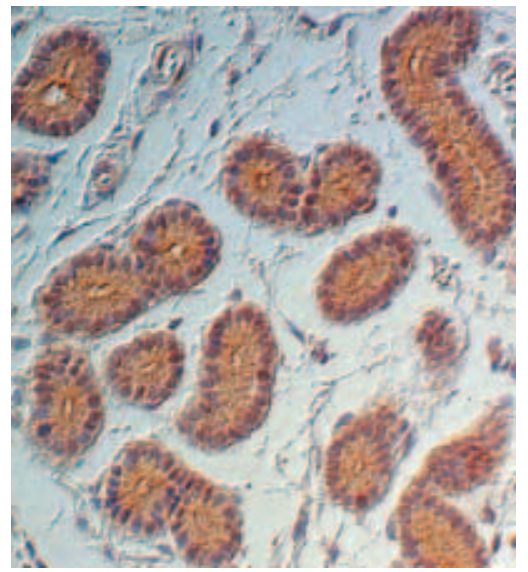

Fig. 5 Cycle dependent glandular expression of the different proteins examined. Uterocalin: Mare B, 10th day post-ovulation, middle uterine gland, all glandular epithelial cells within one gland exhibited the same diffuse intracytoplasmatic expression pattern for uterocalin. Immunohistochemistry, anti-uterocalin, magnification 62,5x.

Zyklusabhängige Expression der untersuchten Proteine in den Uterindrüsen. Uterocalin, Stute B, 10. Tag post-ovulationem, mittlerer Bereich des Stratum spongiosum, diffuses intrazytoplasmatisches, innerhalb der Drüsenquerschnitte gleichmäßiges Expressionsmuster des Uterokalins. Immunhistologie, anti-uterocalin, Vergrößerung $62,5 x$.

release of proteins from secretory vesicles of uterine glands. These results supporting the hypothesis that the synthesis and/or secretion of UGL is influenced by estrogen (Beier-Hellwig et al. 1995).

Detection of expression of UGL requires treatment with progesterone for several days, maybe due to a time-dependent epithelial differentiation initiated and maintained by progesterone (Müller-Schöttle et al. 2000). Accordingly, the increased UGL expression intensity was associated with a decrease in concentrations of serum progesterone. However, the simultaneous rise in both UGL and serum progesterone at proestrus in mare $B$ indicates a rapid reaction of the already differentiated epithelia to a re-exposure to progesterone.

\section{Uteroferrin}

The increase in expression of UF during mid- to late-interestrus as well as the subsequent decrease to low levels is in accordance with results obtained from studies of uterine flushings (Zavy et al. 1982). Additionally, the time-lag of several days before peak staining intensity after concentrations of serum progesterone are maximal supports previous reports for pigs (Schlosnagle et al. 1974). As discussed for UGL this phenomenon could be caused by a time-dependent epithelial differentiation (Simmen et al. 1988). Although there are distinct similarities with the expression pattern for UGL, no variations in the UF staining intensity were detected during proestrus for mare $B$, indicating clear differences in steroid-dependent regulation of these proteins.

\section{Calbindin $_{D 9 k}$}

The maximal staining intensity of CAL during early- to midinterestrus of mares B and C suggests progesterone-dependent synthesis of protein as reported for other species (Inpanbutr et al. 1994, Tatsumi et al. 1999). Furthermore, there was a more rapid increase in CAL expression in response to increases in serum progesterone concentrations including a simultaneous increase of both progesterone and CAL at proestrus of mares $B$ and $C$. The constant low expression of CAL in mare $A$ is probably due to the limited narrow time window for detection of CAL during the estrus cycle of mares.

\section{Uterocalin}

In accordance with previous reports (Stewart et al. 1995), there was a close association between increasing concentrations of serum progesterone and endometrial UCA expression during early- (mare A) to mid-interestrus (mare B and C). Variations among mares with respect to steroid hormone profiles possibly explain differences in patterns of expression of UCA. However, additional control mechanisms must be involved in induction/inhibition of the protein resulting in the second UCA-peak in mare A associated with high estrogen levels and the lack of UCA despite high progesterone levels at proestrus of mare $B$.

\section{Glycogen}

As for UCA, the increase in GLY levels from estrus to midinterestrus in two mares ( $B$ and $C$ ) is in response to a simultaneous increase in serum progesterone concentrations as previously reported for the mare (Gilbert 1992). While stimulation of gluconeogenesis by progesterone is indisputable (Jaffe et al. 1985), few data exist on the control mechanism responsible. Therefore, there may be different explanations, for example a defect in the steroid dependent enzymatic pathway which regulates gluconeogenesis throughout the estrus cycle, which may explain the aberrant pattern of expression of GLY in mare A. Similar to UGL, the apical intracytoplasmatic staining reaction is probably due to transit release of contents of secretory vesicles by uterine gland epithelia.

Functional differences between the superficial and deep glandular epithelia have been reported (Gilbert 1992, Gerstenberg et al. 1999). However the expression pattern of UGL, UF and UCA suggests more extensive functional differences for superficial, middle and deep glandular epithelia. Moreover, the mosaic staining reaction pattern for CAL and GLY indicate among cell differences within a single uterine gland. This hypothesis is supported by the observation that different cells do not react identically and synchrously in their accumulation of GLY after exposure to progesterone (Spornitz 1992). 
In conclusion, the investigated proteins and GLY demonstrated typical patterns of expression throughout the estrus cycle. However distinct differences in expression among the three mares indicate further dynamic interactions in the regulation of the proteins/glycogen which can not be clarified here. A possible role of, for example, the prolactin receptors (Kleis-SanFrancisco et al. 1993) has to be clarified by future studies. The high staining intensities of all proteins and GLY during interestrus confirm the necessity of a proper uterine environment during the pre-implantation and implantation periods of the mare. Furthermore the new methods established here enable pathologists to interpret uterine secretion patterns in fertility reducing diseases by using a single endometrial biopsy.

\section{Ackknowledgements}

Prof. Dr. W. R. Allen kindly provided us with the anti-uterocalin antiserum. Furthermore we are indebted to Mrs. Herzog and Mrs. Schleinitz for preparing the excellent histological slides as well as to Mrs. Wipplinger for her skillful assistance in performing the immunohistochemistry.

\section{Manufacturer's addresses/Source of antibody \\ Medac GmbH, Wedel, Germany \\ 2 Calbiochem-Novabiochem GmbH, Bad Soden, Germany \\ 3 Dr. Klug, Justus v. Liebig University, Gießen, Germany \\ 4 Prof. Dr. Bazer, Texas A\&M University, Texas, USA \\ 5 Prof. Dr. Allen, Equine Fertility Unit, Cambridge, UK \\ 6 CB9, Swant Bellinzona/CH}

\section{Literature}

Amoroso E. C. (1959) Placentation. In: Marshall's Physiology of reproduction, 3rd edn, Parkes AS (Ed.), London: Longman Green., Vol II, 127-311

Aupperle H., Özgen S., Schoon H.-A., Schoon D., Hoppen H. O. and Tannapfel A. (2000) Cyclial endometrial steroid hormone receptor expression and proliferation intensity in the mare. Equine Vet. J. $32,228-232$

Beier H. M. (2000) The discovery of uteroglobin and its significance for reproductive biology and endocrinology. In: The uteroglobin/clara cell protein family, Mukherjee A. B. and Chilton B. S. (Ed), New York: The New York Academy of Science, 9-24

Beier-Hellwig K., Kremer H., Bonn B., Linder D., Bader H. and Beier H. M. (1995). Partial sequencing and identification of three proteins from equine uterine secretion regulated by progesterone. Reprod. Dom. Anim. 30, 295-298

Crosset B., Suire S., Herrler A., Allen W. R. and Stewart F. (1998) Transfer of a uterine lipocalin from the endometrium of the mare to the developing equine conceptus. Biology of Reproduction 59, 483-490

Freeman K. P., Roszel J. F., Slusher S. H. and Castro M. (1990) Variation in glycogen and mucins in the equine uterus related to physiologic and pathologic conditions. Theriogenol. 33, 799-808

Gilbert R. O. (1992) Cyclical changes in equine endometrial histology. Proceedings of the 12th Int Conf Anim Reprod, The Hague 1867-1869

Hoffmann C., Bazer F. W., Klug J., Aupperle H., Ellenberger C. and Schoon H.-A. (2009) Immunohistochemical and histochemical identification of proteins and carbohydrates in the equine endometrium, Expression patterns for mares suffering from endometrosis. Theriogenol. 71, 264-274

Inpanbutr N., Miller E. K., Petroff B. K. and lacopino A. M. (1994) CaBP9K levels during the luteal and follicular phases of the estrus cycle in the bovine uterus. Biol. Reprod. 50, 561-571
Jaffe R. C., Stevens D. M. and Verhage H. G. (1985) The effects of estrogen and progesterone of glycogen and the enzymes involved in its metabolism in the cat uterus. Steroids 45, 453-462

Kikukawa T., Cowan B. D., Tejada R. I. and Mukheriee A. B. (1988) Partial characterization of a uteroglobin-like protein in the human uterus and its temporal relationship to prostaglandin levels in this organ. Journal of Clinical Endocrinology and Metabolism 67, 315-321

Kleis-SanFrancisco S., Heweston A. and Chilton B. S. (1993) Prolactin augments progesterone-dependent uteroglobin gene expression by modulating promoter-binding proteins. Molecular Endocrinol. 7, 214-223

L'Horset F., Blin C., Brehier A., Thomasset M. and Perret C. (1993) Estrogen-induced calbindin-D9k gene expression in the rat uterus during the estrus cycle: late antagonistic effect of progesterone. Endocrinol. 132, 489-495

Müller-Schöttle F., Classen-Linke I., Beier-Hellwig K., Sterzik K. and Beier H. M. (2000) Uteroglobin expression and release in the human endometrium. In: The uteroglobin/clara cell protein family, Mukherjee A. B. and Chilton B. S. (Ed), New York: The New York Academy of Science, 332-335

Müller-Schöttle F., Bogusz A., Herrler A., Bollwein H., Beier-Hellwig K. and Beier H. M. (2003) Cloning of horse uteroglobin and its expression pattern in the endometrium. Proceedings zur 36. Jahrestagung Physiologie und Pathologie der Fortpflanzung; Wien 83

Mukheriee A. B., Kundu G. C., Mantile-Selvaggi G., Yuan C. J., Mandal A. K., Chattopadhyay S., Zheng F., Pattabiramar N. and Zhang Z. (1999) Uteroglobin: a novel cytokine? Cellular and Molecular Life Science 55, 771-787

Nikitenko L., Morgan G., Kolesnikov S. I. and Wooding F. B. P. (1998) Immunocytochemical and in situ hybridization studies of the distribution of Calbindin D9k in the bovine placenta throughout pregnancy. J. Histochem. Cytochem. 46, 679-688

Roberts R. M., Raub T. J. and Bazer F. W. (1986) Role of uteroferrin in transplacental iron transport in the pig. Fedn. Proc. Fedn. Am. Socs. exp. Biol. 45, 2513-2518

Schlosnagle D. C., Bazer F. W., Tsibris J. C. M. and Roberts R. M. (1974) An iron-containing phosphatase induced by progesterone in the uterine fluids of pigs. J. Biolog. Chem. 249, 7574-7579

Schoon H.-A., Schoon D. and Klug E. (1997) Die Endometriumbiopsie bei der Stute im klinisch-gynäkologischen Kontext. Pferdeheilkunde 13, 453-464

Shapiro S. S., Dyer S. D. and Colas A. E. (1980) Progesterone-induced glycogen accumulation in human endometrium during organ culture. Ame. J. Obstet. Gynecol. 136, 419-425

Simmen R. C. M., Baumbach G. A. and Roberts R. M. (1988) Molecular cloning and temporal expression during pregnancy of the messenger ribonucleic acid encoding uteroferrin, a progesterone induced uterine secretory protein. Molecular Endocrinology 2, 253-2562

Spornitz U. M. (1992) The functional morphology of the human endometrium and decidua. Advanc. Anat. Embryol. Cell Biol. 124, 1-99

Stewart F., Charleston B., Crosset B., Barker P. J. and Allen W. R. (1995) A novel uterine protein that associates with the embryonic capsule in equids. J. Reprod. Fertil. 195, 65-70

Tatsumi K., Higuchi T., Fujiwara H., Nakayama T., Itoh K., Mori T., Fujii S. and Fuiita J. (1999) Expression of calcium binding protein $\mathrm{D}$-9k messenger RNA in the mouse uterine endometrium during implantation. Molecul. Hum. Reprod. 5, 153-161

Zavy M. T., Sharp D. C., Bazer F. W., Fazlebas A., Sessions F. and Roberts R. M. (1982) Identification of stage-specific and hormonally induced polypeptides in the uterine protein secretions of the mare during the oestrus cycle and pregnancy. J. Reprod. Fertil. 64, 199207

\section{Christine Hoffmann}

Friedrich-Loeffler-Institute

Federal Research Institute of Animal Health

Institute of Novel and Emerging Infectious Diseases

Boddenblick $5 a$

17493 Insel Riems

christine.hoffmann@fli.bund.de 